\title{
Fixed Dose Combination for TB treatment
}

\author{
Tjandra Yoga Aditama
}

\begin{abstract}
Abstrak
Menurut WHO (World Health Organization) sepertiga penduduk dunia telah terinfeksi dengan tuberkulosis (TB). Sekitar 2 juta orang meninggal akibat penyakit ini setiap tahunnya dan akan muncul lebih dari 8 juta penderita TB baru setiap tahunnya. Selain itu, kembali menurut WHO (2000), jumlah kematian akibat tuberkulosis akan menjadi 35 juta orang pada tahun 2000-2020. Sebagian besar pasien tuberkulosis di dunia masih tetap diobati dengan beberapa obat-obat tunggal, atau mungkin dengan obat TB kombinasi dosis tetap (KDT) yang berisi 2 obat. Untuk meningkatkan mutu hasil pengobatan maka WHO merekomendasikan penggunaan obat TB dalam bentuk TB kombinasi dosis tetap (KDT) yang berisi 2 dan 3 obat dalam strategi DOTS. Sejak 1999, KDT yang berisi 4 obat telah dimasukkan pula dalam "WHO Model List of Essential Drugs". Dewasa ini KDT merupakan alat penting untuk makin meningkatkan mutu pelayanan pada pasien TB, dalam akselerasi program DOTS untuk segera mencapai target global. Obat TB dalam bentuk kombinasi dosis tetap (KDT) dapat menyederhanakan cara pengobatan dan juga manajemen pengelolaan / distribusi obat TB serta mampu mencegah timbulnya resistensi. KDT menyederhanakan cara pengobatan karena jumlah tablet yang harus ditelan pasien akan berkurang, ddari 15 - 16 buah menjadi 3 - 4 buah saja, dan juga menurunkan kesalahan penulisan resep. Juga jauh lebih mudah untuk menerangkan kepada pasien bahwa ia harus makan 4 tablet yang sejenis, daripada harus makan berbagai tablet dalam berbagai bentuk dan warna yang berbeda. Kemungkinan tidak memakan semua obat yang diharuskan juga dapat dicegah karena satu obat KDT sudah merupakan campuran dari beberapa obat sekalligus. KDT juga akan memudahkan para dokter dan petugas kesehatan karena hanya harus mengingat satu macam obat, lebih sederhana dan tidak membingungkan. Akhirnya, seluruh aspek distribusi obat (pembelian, pengapalan, penggudangan) juga jauh lebih sederhana dalam bentuk KDT ini.Efek samping obat tidaklah akan bertambah bila kita menggunakan KDT. Bila terjadi juga efek samping maka mungkin diperlukan obat dalam bentuk tunggal. Kualitas, keamanan dan efektivitas KDT ditentukan oleh proses pembuatannya, artinya seberapa jauh produsen mematuhi kaidah "good manufacturing practices (GMP)" dan spesifikasi farmakopea. Pengelola program TB nasional harus membuat sistem jaga mutu ("QA system”). Dalam hal ini WHO telah membangun jaringan laboratorium untuk menilai KDT yang ada sesuai dengan permintaan pihak industri farmasi. (Med J Indones 2003; 12: 114-9)
\end{abstract}

\begin{abstract}
According to the World Health Organization, a third of the world's population is infected with tuberculosis. The disease is responsible for nearly 2 million deaths each year and over 8 million were developing active diseases. Moreover, according to WHO (2000), tuberculosis deaths are estimated to increase to 35 million between 2000-2020. The majority of tuberculosis patients worldwide are still treated with single drugs, or with 2-drug fixed-dose combinations (FDCs). To improve tuberculosis treatment, 2- and 3-drug FDCs were recommended by the World Health Organization (WHO) as part of the DOTS strategy. Since 1999 a 4-drug FDC was included on the WHO Model List of Essential Drugs. Today, FDCs are important tools to further improve the quality of care for people with TB, and accelerate DOTS expansion to reach the global TB control targets. Fixed dose combination TB drugs could simplifies both treatment and management of drug supply, and may prevent the emergence of drug resistance. Prevention of drug resistance is just one of the potential benefits of the use of FDCs. FDCs simplify administration of drugs by reducing the number of pills a patient takes each day and decreasing the risk of incorrect prescriptions. Most tuberculosis patients need only take 3-4 FDCs tablets per day during the intensive phase of treatment, instead of the 15-16 tablets per day that is common with single-drug formulations It is much simpler to explain to patients that they need to take four tablets of the same type and colour, rather than a mixture of tablets of different shapes, colours and sizes. Also, the chance of taking an incomplete combination of drugs is eliminated, since the four essential drugs are combined into one tablet. FDCs are also simpler for care-givers as they minimize the risk of confusion. Finally, drug procurement, in all its components (stock management, shipping, distribution), is simplified by FDCs. Adverse reactions to drugs are not more common if FDCs are used. Nevertheless, whenever side-effects to one or more components in a FDC are suspected, there will be a need to switch to single-drug formulations. Quality, safety and efficacy of FDC drugs are determined by the manufacturing process i.e. by compliance of the manufacturer with the requirements of good manufacturing practices (GMP) and pharmacopoeial specifications. National TB programmes must establish a QA system WHO established a laboratory network that tests the quality of FDCs in the marketplace and registers products upon request from the pharmaceutical industry. (Med J Indones 2003; 12: 114-9)
\end{abstract}

Keywords: fixed dose combination, tuberculosis, treatment

Pulmonology and Respiratory Medicine Department

Faculty of Medicine University of Indonesia / Persahabatan Hospital,

Jakarta, Indonesia 
One third of world's population is infected with tuberculosis (TB). From this pool, roughly 9 million cases of active TB emerge annually, resulting in $2-$ million deaths. Most new cases occur in most populated nation, India and China, but the highest rates of diseases are seen in sub-Saharan Africa, the Indonesian and Philippines archipelago, Afghanistan, Bolivia and Peru. Every day more than 23,000 people develop active tuberculosis, and close to 5000 die from the diseases. Moreover, tuberculosis deaths are estimated to increase to 35 million between 20002020. WHO declared a global TB emergency in 1993. However, political commitment to control the growing pandemic was lacking and TB continued to exact its remorseless toll. ${ }^{1,2}$

Indonesia has the third largest number of TB cases in the world. There are one new tuberculosis patient exist every minute in Indonesia, there are 2 smear positive new cases in every two minutes and there are one death due to tuberculosis occur in Indonesia in every 4 minutes. ${ }^{3}$

DOTS were choose the best control program to overcome TB problems in countries in the world. Despite widespread acceptance of the principles of DOTS, many countries have not been able to expand DOTS as rapidly as needed and have failed to achieve the year 2000 global target of detecting $70 \%$ of the infectious cases and curing $85 \%$ of those detected. The main constraints to rapid expansion, as identified by an ad-hoc Committee on the Tuberculosis Epidemic held in London in 1998, were lack of political commitment, insufficient and ineffective use of financial resources, neglect of human resource development, poor health system organization and TB managerial capability, inadequate quality and irregular supply of anti-TB drugs, and lack of information. Globally, 55\% of the human population in principle had access to DOTS in 2000. However, due to incomplete service coverage, only $27 \%$ of all estimated cases were detected in DOTS program. ${ }^{3,4}$

\section{TB TREATMENT}

Talking about treatment, one key element of the DOTS strategy is the use of short-course chemotherapy regimens, proven by clinical trials to be highly efficacious, under proper case management conditions. This includes direct observation of patients taking their drugs at the correct dosage and for the proper period of time, the concept what we called as DOT.
Directly observed treatment (DOT) means that a supervisor watches the patient swallowing the tablets. This ensures that a TB patient takes the right drugs, in the right doses, at the right intervals. DOT is applicable in outpatient settings. The supervisor may be a health worker or a trained and supervised member of the community. Patients' and health workers' compliance is a key factor in treatment success. ${ }^{1}$

TB regimens and anti-TB drug formulations have changed regularly in the past in response to new insights and circumstances in TB control. The introduction of rifampicin in the 1970s is a radical change and shortened the regimen from 12-18 months to 6-8 months (short course chemotherapy: SCC). In the 1990s, SCC was expanded worldwide together with the expansion of DOTS strategy. Anti tuberculosis drugs and its dosage could be seen in Table 1.,3,5

Table 1. Recommended doses of essential tuberculosis drugs

\begin{tabular}{llll}
\hline \multirow{2}{*}{$\begin{array}{c}\text { Antituberculosis } \\
\text { drug }\end{array}$} & $\begin{array}{c}\text { Mode of } \\
\text { action }\end{array}$ & \multicolumn{2}{c}{$\begin{array}{c}\text { Recommended dose \& } \\
\text { range }\end{array}$} \\
\cline { 3 - 4 } & & Daily & 3x per week \\
\hline Isoniazid & Bactericidal & $5(4-6)$ & $10(8-12)$ \\
Rifampicin & Bactericidal & $10(8-12)$ & $10(8-12)$ \\
Pyrazinamide & Bactericidal & $25(20-30)$ & $35(30-40)$ \\
Ethambutol & Bacteriostatic & $15(15-20)$ & $30(25-35)$ \\
Streptomycin & Bactericidal & $15(12-18)$ & $15(12-18)$ \\
\hline
\end{tabular}

From the WHO Model List of Essential Drugs, 1999

(cited from ref $5 \& 7$ ).

Treatment using more than one drug is based on 2 principles, preventing acquired drug resistance and enhancing efficacy. Tubercle bacilli undergo random chromosomal mutation that have made them resistant to every drug used to treat TB. Fortunately this mutation are infrequent. Because they are unlinked (in terms of chromosomal location or function) and specific to a drug or drug class, spontaneous generation of an organism with multi resistance is extremely improbable. ${ }^{6}$

On the other hand, for chemotherapy to be a success, it must not only prevent drug resistance, but also kill all, or almost all, of the drug-susceptible organism, to prevent their subsequent multiplication and a resultant relapse after cessation of treatment. ${ }^{5,6}$

\section{FIXED DOSE COMBINATION (FDC)}

The majority of tuberculosis patients worldwide are still treated with single drugs, or with 2-drug fixed- 
dose combinations (FDCs). To improve tuberculosis treatment, 2- and 3-drug FDCs were recommended by the World Health Organization (WHO) as part of the DOTS strategy (Table 2). 5,7

More recently, the majority of countries using DOTS strategy have replaced rifampicin and isoniazid loose tablets with combination tablets (2-drug FDCs [RH]) as recommended by WHO and IUATLD since 1994. There are no new regimens for programmes using the 4-drug FDC. The WHO-recommended 4-drug FDC consists of $150 \mathrm{mg}$ rifampicin, $75 \mathrm{mg}$ isoniazid, 400 $\mathrm{mg}$ pyrazinamide and $275 \mathrm{mg}$ ethambutol. This is suitable for daily regimens. WHO also recommends a number of 2- and 3-drug FDCs.

The 4-drug FDC is simply a vehicle for delivering short-course chemotherapy in a more reliable fashion. The only difference is that the 4-drug FDC is used during the intensive treatment phase, instead of single-drug formulations, or 2- or 3-drug FDCs. The previously-recommended regimens still apply, and in the continuation phase a 2-drug FDC should be used. ${ }^{5,7,8}$

The rationale for recommending the 4-drug FDC is that it simplifies both treatment and management of drug supply, and may prevent the emergence of drug resistance. $^{7,8}$

Simplifying treatment. The 4-drug FDC may increase compliance with treatment because most tuberculosis patients need only take 3-4 tablets per day during the intensive phase of treatment (table 3), instead of the 15-16 tablets per day that is common with single-drug formulations. Also, the chance of taking an incomplete combination of drugs is eliminated, since the four essential drugs are combined into one tablet. Studies have shown that prescriptions for tuberculosis treatment are complex and that prescription errors are common. Therefore, with the 4-drug FDC it is easier to calculate the required dosage compared to single drug formulations.

Simplifying management of drug supply. Using a 4drug FDC means there are fewer formulations to order and distribute, thus simplifying the management of drug supply. However, countries will still need to maintain small stocks of single-drug formulations at referral centers to treat adverse reactions.
Preventing drug resistance. Multidrug-resistant tuberculosis is emerging throughout the world. The causes include erratic drug intake (particularly interruptions of treatment), and treatment with a single antituberculosis drug. A 4drug FDC simplifies treatment and virtually eliminates the risk of monotherapy, thereby reducing the risk that drug-resistant strains of Mycobacterium tuberculosis will arise.

As a conclusion, the potential advantages of FDCs in treating TB include: $:^{5,7,8}$

- simplicity of treatment with minimal prescription errors;

- increased patient acceptance and compliance with decreased likelihood of

- inadvertent medication errors;

- increased health worker compliance to standardized and correct treatment;

- improved drug management because ordering, procurement, distribution and

- dispensing/handling at different levels of the NTP are easier when there are fewer

- items with a single expiry date to deal with;

- lowered risk of misuse of single drugs and of emergence of drug-resistant TB due to reduced use of monotherapy.

Table 2. Recommended FDCs for antituberculosis drugs. ${ }^{\mathrm{a}}$

\begin{tabular}{|c|c|c|}
\hline Drug $^{b}$ & Form & Drug strengths for daily use \\
\hline RHZE & Tablet & $\begin{array}{l}\mathrm{R}(150 \mathrm{mg})+\mathrm{H}(75 \mathrm{mg})+\mathrm{Z}(400 \mathrm{mg}) \\
+\mathrm{E}(275 \mathrm{mg}) .\end{array}$ \\
\hline RHZ & Tablet & $\begin{array}{l}\mathrm{R}(150 \mathrm{mg})+\mathrm{H}(75 \mathrm{mg})+\mathrm{Z}(400 \mathrm{mg}) \\
\mathrm{R}(60 \mathrm{mg})+\mathrm{H}(30 \mathrm{mg})+\mathrm{Z}(150 \mathrm{mg}) \\
\text { For pediatric use. }^{\mathrm{c}}\end{array}$ \\
\hline RH & Tablet & $\begin{array}{l}\mathrm{R}(300 \mathrm{mg})+\mathrm{H}(150 \mathrm{mg}) \\
\mathrm{R}(150 \mathrm{mg})+\mathrm{H}(75 \mathrm{mg}) . \\
\mathrm{R}(60 \mathrm{mg})+\mathrm{H}(30 \mathrm{mg}) . \text { For pediatric use. }\end{array}$ \\
\hline $\mathrm{EH}$ & Tablet & $\mathrm{H}(150 \mathrm{mg})+\mathrm{E}(400 \mathrm{mg})$ \\
\hline $\mathrm{TH}$ & Tablet & $\begin{array}{l}\mathrm{T}(50 \mathrm{mg})+\mathrm{H}(100 \mathrm{mg}) \\
\mathrm{T}(150 \mathrm{mg})+\mathrm{H}(300 \mathrm{mg})\end{array}$ \\
\hline Drug & Forms & Drug strengths for use 3 times a week \\
\hline RHZ & Tablet & $\mathrm{R}(150 \mathrm{mg})+\mathrm{H}(150 \mathrm{mg})+\mathrm{Z}(500 \mathrm{mg})$. \\
\hline RH & Tablet & $\begin{array}{l}\mathrm{R}(150 \mathrm{mg})+\mathrm{H}(150 \mathrm{mg}) . \\
\mathrm{R}(60 \mathrm{mg})+\mathrm{H}(60 \mathrm{mg}) . \text { For pediatric use. }\end{array}$ \\
\hline
\end{tabular}

a From the WHO Model List of Essential Drugs, 1999 (cited from ref $5 \& 7$ ).

b Drug symbols: $\mathrm{E}=$ =thambutol; $\mathrm{H}=$ isoniazid; $\mathrm{R}=$ rifampicin; $\mathrm{S}=$ streptomycin; $\mathrm{T}=$ thioacetazone; $\mathrm{Z}=$ pyrazinamide.

c Dispersible form preferred. 
Table 3. Dosage schedule for FDCs. ${ }^{a}$

\begin{tabular}{|c|c|c|c|c|c|c|c|c|}
\hline \multirow[t]{3}{*}{ Patient } & \multirow[t]{3}{*}{ Body weight (kg) } & \multicolumn{3}{|c|}{ Intensive phase } & \multicolumn{4}{|c|}{ Continuation phase } \\
\hline & & \multicolumn{3}{|c|}{ (2 months) } & \multicolumn{2}{|c|}{ (4 months) } & \multicolumn{2}{|c|}{ (6 months) } \\
\hline & & RHZE $^{\text {b }}$ & RHZ & RHZ 3/7 ${ }^{\mathrm{c}}$ & $\mathbf{R H}^{\mathrm{d}}$ & RH 3/7 ${ }^{\mathrm{d}}$ & EH & $\mathbf{T H}^{\mathrm{e}}$ \\
\hline \multirow[t]{4}{*}{ Children $^{f}$} & $\leq 7$ & & 1 & 1 & 1 & 1 & & \\
\hline & $8-9$ & & 1.5 & 1.5 & 1.5 & 1.5 & & 0.5 \\
\hline & $10-14$ & & 2 & 2 & 2 & 2 & & 0.5 \\
\hline & $15-19$ & & 3 & 3 & 3 & 3 & & 1 \\
\hline \multirow[t]{4}{*}{ Adults } & $30-37$ & 2 & 2 & 2 & 2 & 2 & 1.5 & 1.5 \\
\hline & $38-54^{g}$ & 3 & 3 & 3 & 3 & 3 & 2 & 2 \\
\hline & $55-70$ & 4 & 4 & 4 & 4 & 4 & 3 & 3 \\
\hline & $\geq 71$ & 5 & 5 & 5 & 5 & 5 & 3 & 4 \\
\hline \multicolumn{9}{|c|}{ a From the WHO Model List of Essential Drugs, 1999} \\
\hline \multicolumn{9}{|c|}{$\begin{array}{l}\text { The schedules represent the daily number of tablets to be taken that contain the corresponding combinations of drugs at WHO- } \\
\text { recommended strengths. }\end{array}$} \\
\hline \multicolumn{9}{|c|}{$\begin{array}{l}\text { For programmes that use EH in the continuation phase of treatment for new cases, new national guidelines for treatment propose } \\
\text { that the 4-drug FDC could be used in the continuation phase for retreatment cases (WHO treatment category \#2), even though this } \\
\text { has not yet been properly evaluated or agreed upon. }\end{array}$} \\
\hline \multicolumn{9}{|c|}{ c " $3 / 7 "$ means the formulation is used three times a week. } \\
\hline \multirow{2}{*}{\multicolumn{9}{|c|}{$\begin{array}{l}\text { In the continuation phase for adults, the RH formulation } \mathrm{R}(150 \mathrm{mg})+\mathrm{H}(75 \mathrm{mg}) \text { should be used for daily treatment, and } \mathrm{R}(150 \\
\mathrm{mg})+\mathrm{H}(150 \mathrm{mg}) \text { should be used for intermittent treatment. } \\
\text { e Numbers of tablets based on the TH formulation of } \mathrm{T}(50 \mathrm{mg})+\mathrm{H}(100 \mathrm{mg}) \text {. Thioacetazone containing FDCs are used for daily } \\
\text { treatment. Thioacetazone should not be used in intermittent regimens. }\end{array}$}} \\
\hline & & & & & & & & \\
\hline \multicolumn{9}{|c|}{$\begin{array}{l}\text { Ethambutol-containing FDCs }(\mathrm{EH}) \text { are best avoided in children owing to the risk of dose-dependent optic neuritis. RHZE, } \\
\text { however, can be used in the intensive phase for paediatric patients who are smear-positive for tuberculosis or have miliary } \\
\text { tuberculosis. }\end{array}$} \\
\hline \multicolumn{9}{|c|}{$\begin{array}{l}\text { The composition of the 4-drug FDC ensures adequate doses of the drugs even when } 50 \mathrm{~kg} \text { is chosen as the cut-off point for changing } \\
\text { between } 3 \text { and } 4 \text { tablets per day. }\end{array}$} \\
\hline
\end{tabular}

Circumstantial evidence of the benefits of FDC-based treatment comes from the low rates of multidrugresistant tuberculosis in countries, such as Brazil, and South Africa where good quality FDCs have been used for some time. Clinical trials in Algeria and Hong Kong found that 3-drug FDCs were as efficacious as single-drug formulations. A clinical trial comparing the WHO-recommended 4-drug FDC with conventional formulations has been planned by the IUATLD clinical trials network. DOT is recommended in the initial phase of treatment with FDCs, at least for all smear-positive cases, and in the continuation phase of rifampicin-containing (intermittent and daily) regimens. ${ }^{7,9,10}$

As a whole, FDC tablets will contribute tremendously to DOTS expansion in several ways: ${ }^{7}$

- there will be no more monotherapy with one medicine or an insufficient number of different loose drugs, reducing the chance of development of resistant strains of TB;

- the 4-drug FDC regimen decreases the risk of treatment failure and relapse;
- patients will have fewer tablets to swallow, which will help improve compliance;

- having fewer tablets to handle, supervision of drug intake will be quicker, so greatly reducing the workload and potential prescription errors of health

- workers administering DOTS;

- drug ordering, storage and stock control will be simpler and time will be saved, while errors are less likely to occur (fewer items to handle with the same expiry date);

- from the programme management point of view, calculation of drug needs, procurement, distribution and stocking throughout the programme will become

- simpler and, in some instances, even cheaper (e.g. due to less volume and storage capacity needed); and

- it will be easier to adjust dosages by body weight

\section{SIDE EFFECTS AND BIOAVAILABILITY}

In the few cases when patients on 4-drug FDCs suffer serious enough adverse effects that treatment has to be 
modified, they need to be referred to a hospital where single-drug tablets are available. Patients with serious adverse drug reactions should be referred to, and managed in, referral hospitals with special competence, and which store alternative drug formulations. The distribution of a limited amount of single-drug formulations to these centres is a minor operational disadvantage compared to the advantage that 4-drug FDCs have in simplifying drug management, including simplifying distribution to peripheral treatment centres. ${ }^{5,7}$

All forms of rifampicin, whether as a single drug or in combination with other drugs, can have quality problems that result in unsatisfactory bioavailability. There are indications that poor-quality pharmaceutical products are common, particularly in countries with limited resources for regulatory institutions and it is reasonable to assume that both FDCs and single-drug formulations have quality problems. Treatment of TB with poor quality drugs will not only result in treatment failures but can lead to the development of drug resistance. This will have a deleterious effect on the health of the wider population. Ensuring the quality, safety and efficacy of all anti-TB drugs, including FDCs, used in a NTP, is therefore of utmost importance in combating the disease. Several meetings between WHO, collaborators and pharmaceutical industry representatives addressed standardization, quality and regulatory issues surrounding FDCs. The pharmaceutical industry reacted swiftly and several manufacturers now produce 4-drug FDCs of WHOrecommended strength and proven bioavailability. ${ }^{9,10}$

\section{QUALITY}

Safety, efficacy and quality are built into a product at the time of its design and production. This means that quality, safety and efficacy of FDC drugs are determined by the manufacturing process i.e. by compliance of the manufacturer with the requirements of good manufacturing practices (GMP) and pharmacopoeial specifications. However, a FDC product which has been produced in full compliance with GMP requirements and has passed all laboratory tests, may lose its quality and eventually become ineffective if the packaging, storage and transportation conditions are substandard. ${ }^{7,9}$

While the bioavailability of rifampicin in some FDCs was satisfactory, this was not true of others. The differences appeared to be related to deficiencies in the manufacturing process. Unfortunately, an apparently satisfactory in vitro dissolution test does not guarantee adequate rifampicin bioavailability. As a result, WHO and IUATLD recommended using only FDCs with proven bioavailability. ${ }^{8,9}$

Consequently, in order to ensure that FDC products are safe, effective and of good quality, national TB programmes must establish a QA system WHO established a laboratory network that tests the quality of FDCs in the marketplace and registers products upon request from the pharmaceutical industry. Currently, there are two laboratories in the network: the National Tuberculosis Research Programme, Medical Research Council, Pretoria, South Africa (MRC); and the Department of Pharmaceutics, National Institute of Pharmaceutical, Education and Research, Punjab, India (NIPER). ${ }^{7}$

National Tuberculosis Program (NTP) managers and or medical doctors in a country must insist that the product in the national market meets all quality requirements, and manufacturers/suppliers should provide all required documentation, including documentation of satisfactory bioavailability. Proof that the constituent drugs have satisfactory bioavailability is strictly required, particularly for rifampicin. If the manufacturer/supplier does not provide proof, the NTP manager and or medical doctors in a country should demand that this be performed at the expense of the manufacturer / supplier. Bioavailability testing can be performed by the WHO laboratory network for quality control of FDCs. NTPs may also obtain 4-drug FDCs through the Global Tuberculosis Drug Facility, which supplies 4-drug FDCs of WHO-recommended strengths and of proven quality. Under no circumstances should NTP managers accept 4-drug FDCs that do not meet the required quality standards.

Finally, today, the 148 countries that have adopted DOTS are intensifying their efforts to achieve the targets set for 2005 by the World Health Assembly: to detect $70 \%$ of sputum smear-positive infectious cases and to cure at least $85 \%$ of such cases. With the poor access to adequate health services, including essential medicines, in many countries, the spread of human immunodeficiency virus/acquired immunodeficiency syndrome (HIV/AIDS), and the emergence of multidrug-resistant tuberculosis (MDR-TB), greater efforts are urgently needed to combat the worsening impacts of TB. 
Ensuring that people with TB complete a full course of treatment is one of the major challenges for TB control. The risk is that uninformed patients (as well as uninformed and careless doctors) may change the regimen, avoiding one or more of the drugs they believe are no longer necessary, leading to treatment failure or relapse. Direct observation of treatment is essential to help patients stay on treatment, even after symptoms have subsided following the first few weeks of chemotherapy. Fixed dose combination TB drugs could simplifies both treatment and management of drug supply, and may prevent the emergence of drug resistance. However, prevention of drug resistance is just one of the potential benefits of the use of FDCs. FDCs simplify administration of drugs by reducing the number of pills a patient takes each day and decreasing the risk of incorrect prescriptions. It is much simpler to explain to patients that they need to take four tablets of the same type and colour, rather than a mixture of tablets of different shapes, colours and sizes. FDCs are also simpler for care-givers as they minimize the risk of confusion. Finally, drug procurement, in all its components (stock management, shipping, distribution), is simplified by FDCs.

\section{REFERENCES}

1. Pio A, Chaulett P. Tuberculosis Handbook. Geneva : WHO $1998: 15-6$

2. Kumaresan J. The Global Partnership to stop TB. Inter J Tuberc Lung Dis 2002;10(6): S1

3. Tjandra Yoga Aditama. Tuberkulosis. Jakarta : Yayasan Penerbit IDI $2002: 54$

4. Raviglione MC. Global DOTS expansion : will we reach the targets? Inter J Tuberc Lung Dis 2002;10(6): S8

5. World Health Organization. Operational Guide for National Tuberculosis Control Program on the introduction and use of fixed-dose combination drugs. Geneva : World Health Organization 2002 : 5-6.

6. Chan ED, Iseman MD. Current medical treatment for tuberculosis. BMJ 2002;325:1282-6

7. World Health Organization. The 4 drugs fixed-dose combination tablet recommended by WHO for treating tuberculosis. Geneva : World Health Organization 2002 : $2-10$

8. Blomberg R, Spinaci R, Fourie J, Laing K. the rationale for recommending FDC tablets for treatment of TB. Bulletin of the WHO 2001; 79: 61-8

9. Pablos-Mendez A, Raviglione MC, Laszlo A, Binkin N, Rieder HL, Bustreo F et al. Global surveillance for antituberculosis-drug resistance, 1994-1997. New England J Med 1998;338:1641-9.

10. Pillai G, Fourie PB, Padayatchi N, Onyebujoh PC, McIlleron $\mathrm{H}$, Smith PJ et al. Recent bioequivalence studies on fixed-dose combination anti-tuberculosis drug formulations available on the global market. Inter $\mathbf{J}$ Tuberc Lung Dis 1999;3:S309-S316; discussion S17S21. 